\title{
Use of hoof boot for the treatment of foot lesions in dairy cows
}

\author{
İbrahim DEMİRKAN \\ Department of Surgery, Faculty of Veterinary Medicine, Afyon Kocatepe University, Afyon
}

\begin{abstract}
Summary: In this study, it was evaluated the effectiveness of hoof boot on the treatment of digital and interdigital dermatitis. A total of 80 Friesian-Holstein cows were divided into two groups, each consisting of 40 cows. Group I (GI) contained cows suffering from digital dermatitis whereas group II (GII) contained cow with interdigital dermatitis. GI was further divided into four subgroups; in GI-a $(n=10)$ feet were sprayed with oxytetracycline and hoof boot was applied; in GI-b $(n=10)$ feet were sprayed with only saline solution and hoof boot was applied. Whereas in GI-c $(n=10)$ lesions were left open and sprayed with oxytetracycline; in GI-d $(n=10)$ lesions were left open and only saline solution was applied. GII $(n=40)$ was also divided into 4 subgroups as for GI. Lameness disappeared in GI-a and GII-a within 3 days and healing of lesions occurred between 9 and 14 days after single application. In GI-b and GII-b lesions persisted and two more applications required. Healing in these groups occurred within $21-29$ days. Differences between groups were statistically significant $(\mathrm{p}<0.01)$. Therefore, it was concluded that use of hoof boot adjacent to the treatment of digital or interdigital dermatitis has dramatically improved the healing process.
\end{abstract}

Key words: Cattle, hoof boot, lameness, treatment

\section{Süt sığırlarında ayak lezyonlarının sağaltımında ayak çizmesi kullanımı}

Özet: Bu çalışmada sığırlarda ayak çizmesinin digital ve interdigital dermatitis'in sağaltımındaki etkisi araştırıldı. Toplam 80 adet Friesian-Holstein süt ineği çalışmaya dahil edildi. Herbiri 40 inekten oluşan iki gruba ayrıldı. Grup I'i digital dermatitisli, grup II'yi interdigital dermatitisli inekler oluşturdu. Grup I (GI) tekrar 4 alt gruba ayrıldı; GI-a'da $(n=10)$ bulunanlara ayak çizmesi giydirilip oxytetrasiklin uygulanirken GI-b'dekilere $(n=10)$ ayak cizmesi giydirilip sadece serum fizyolojik tatbik edildi. G-Ic'de (n=10) ise lezyon acık bırakılıp sadece oksitetrasiklin uyguland, G-Id sadece serum fizyolojik ile muamele edildi. G-II'deki $(n=40)$ ineklerde aynı grup I'dekiler gibi alt gruplara ayrılıp işlem yapıldı. GI-a ve GII-a'da topallık ortalama 3 gun icerisinde duzelirken lezyonların ortalama 9-14 gün içerisinde tek uygulamayı izleyerek iyileştiği görüldü. GI-b ve GII-b'de ise iyileşme 21-29 gün içerisinde 2 uygulamadan sonra gozlendi. Gruplar arası farklılıklar istatistiksel olarak anlamlı bulundu $(\mathrm{p}<0.01)$. Sonuç olarak enfeksiyöz karakterli parmak hastalıklarında yaygın olarak uygulanan oksitetrasiklin sağaltımında ayak çizmelerinin kullanımının lezyonıarın iyileşmesini dramatik olarak hızlandırdığı gözlendi

Anahtar kelimeler: Ayak çizmesi, sağaltım, sı̆̆ır, topallık

\section{Introduction}

Lameness can be defined as the incapability of normal locomotion, characterized by deviation from its normal gait (5). It is an important clinical manifestation affecting the dairy industry; because affected cows have poor welfare through disease, or abnormality of the musculoskeletal system originating from pain in a limb or its supporting structures (13). Foot lameness is a major disease problem in housed dairy cattle $(21,22,29)$.

The economic performance of cows is adversely affected by lameness in a variety of ways $(2,29)$; through loss of milk production $(11,15,23)$ and milk being discarded because it contained antimicrobials that were used to treat infectious cause of lameness (11); through lowered fertility (9), loss of body weight and condition (10) and premature culling $(3,30)$; because of the true cost associated with both veterinary and farmer treatments, particularly foot rot and digital dermatitis.

From the economic point of view, lameness is an emerging problem worldwide with special concern for farmers $(16,23)$.
Treatment of foot lesions basically involves two options; (a) individual and (b) herd basis treatment. To treat infection on a herd basis, footbaths are highly recommended as an easy and effective method (27). Individual treatment includes scrubbing the lesion thoroughly with a running pressure water and a stiff brush to leave a clean open wound, removing all under-run horn where necessary, spraying the lesion with appropriate antimicrobials and daily parenteral administration of antibacterials $(8,14,24,25)$.

This paper aimed to evaluate the effectiveness of hoof boot for the treatment of foot lesions such as digital dermatitis and interdigital dermatitis in dairy cows.

\section{Materials and Methods}

Hoof boot (Bou-Matic, USA) is a plastic based animal shoe that can adapt itself to cows' feet (Figure 1). It has strong and versatile nature protecting the feet against outer offensive substances.

A total of 80 Friesian-Holstein cattle were used in the study. Cows were allocated into two groups; each 
group had 40 cows. Group I contained cows $(n=40)$ with dig:tal dermatitis (DD) whereas group II contained cows $(n=40)$ suffering from interdigital dermatitis (IDD). Cows were severely lame and reluctant to move due to pain.

Prior to the application of oxytetracyline (Pfizer) feet of all cows were vigorously cleaned by tap water, dried and the lesions were observed. Claw was trimmed where necessary by removing eroded horns.

Group I was further divided into four subgroups. In group I-a feet were sprayed with oxytetracycline and hoof boot was applied (Figure 2). In group I-b feet was washed with saline solution and hoof boot was applied. Whereas in group I-c feet were sprayed with oxtetracycline and left open and in group I-d feet were washed with only saline solution and left open. Group II was also divided into 4 subgroups as for group I and similar approach was used (Groups II-a, II-b, II-c and II-d)

Each foot was daily examined for the development of lesions and improvement of locomotion.

Statistics: Minitab package program was used to analyze the data (18). Differences for the independent groups (non-parametric analyses) were measured using Mann-Whitney U-test. Significance level was set at $\mathrm{p}<0.05$.

\section{Results}

Lesions were exclusively located at the rear feet, only two animals had IDD lesions at the front feet. DD was seen as circumscribed inflammation at the plantar aspect of the interdigital space just above the cleft, midway between the heel bulbs. After cleaning the lesion; an irregular, circular area covered with superficial erosion or ulceration with visible granulation tissues was observed. Lameness was severe.

In IDD, there was a foetid smell and dermal involvement in the interdigital area. Superficial erosion and ulceration with serous or grayish exudates were present. Lameness was moderate.

Following a single application in groups I-a and IIa, the locomotion of cows was markedly improved within 3 days. Lesions were healed without any complication (Figure $3 \mathrm{~A}$ and $3 \mathrm{~B}$ ) but, in groups I-b and II-b lameness signs continued. Therefore, their feet had to be sprayed two more occasions for 2 days intervals. Lameness and typical lesions of DD and IDD disappeared within 21-29 days in these groups. However, in GI-d no healing was observed within 30 days and papillamotous form of digital dermatitis developed (Figure 4).

Table 1. Days of disappearance of lameness and healing of lesions in groups I and II.

Tablo 1. Grup I ve II'de topallığın kaybolduğu ve lezyonların iyileştiği günler.

\begin{tabular}{lllllllll}
\hline & \multicolumn{3}{c}{ Group I (day) } & \multicolumn{4}{c}{ Group Il } \\
\hline & Ia & $2 \mathrm{a}$ & Ic & $2 \mathrm{c}$ & $1 \mathrm{~b}$ & $2 \mathrm{~b}$ & $1 \mathrm{~d}$ & $2 \mathrm{~d}$ \\
Lameness & 3.1 & 6.6 & 9.2 & 14.0 & 3.7 & 7.0 & 11.0 & 14.0 \\
Lesions & 14.0 & 26.0 & 29.0 & 30.0 & 9.7 & 15.0 & 21.0 & 30.0 \\
\hline
\end{tabular}

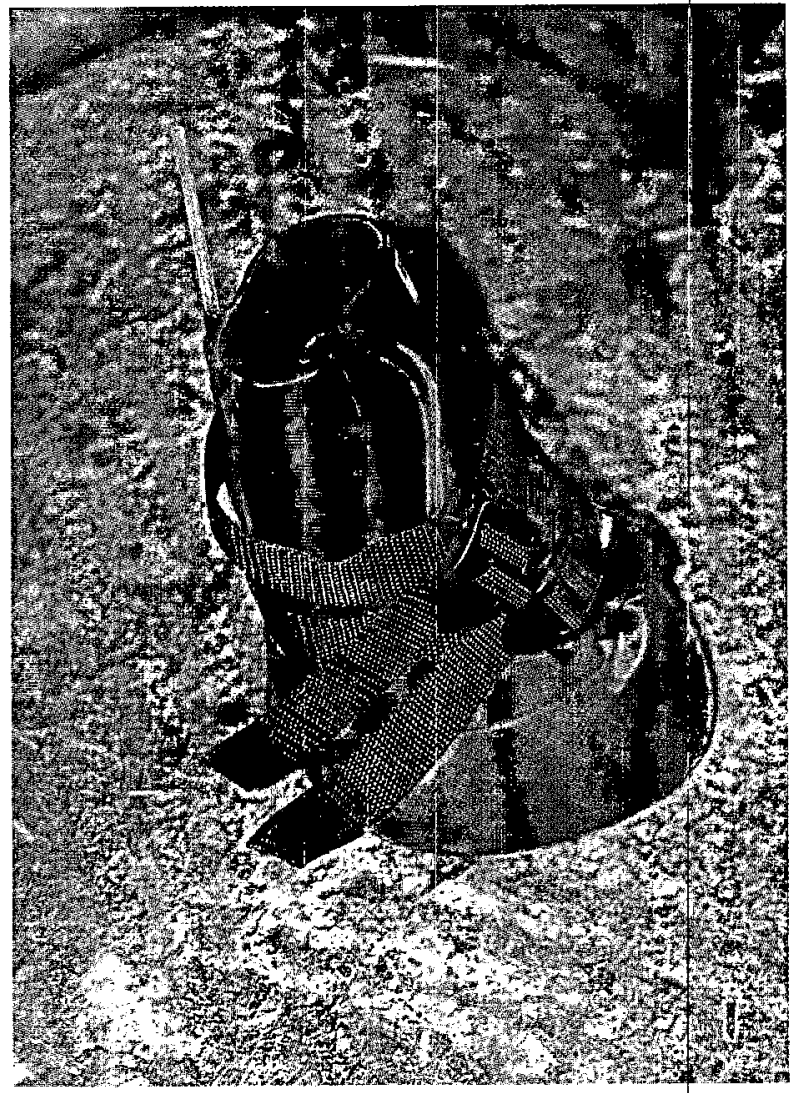

Figure 1. Hoof boot used in this study: Şekil 1. Bu çalışmada kullanılan ayak çizmesi.

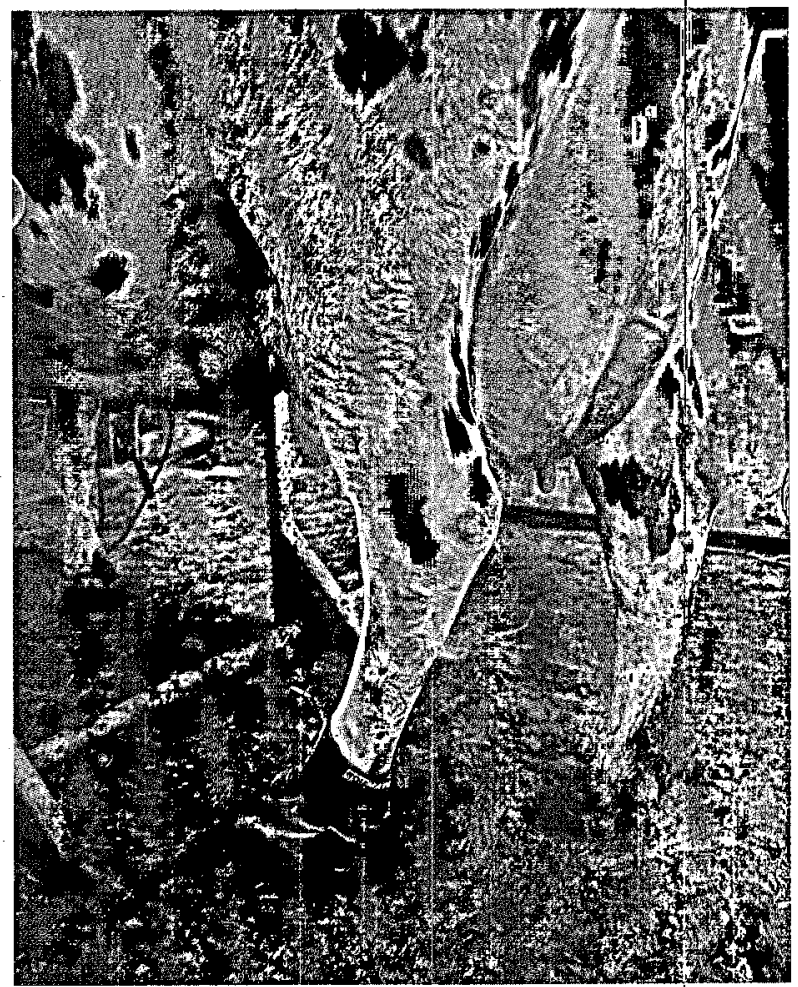

Figure 2. Application of hoof boot to a cow with digital lesion. Şekil 2. Parmak lezyonu olan bir inekte ayak çizmesinin uygulanışı . 


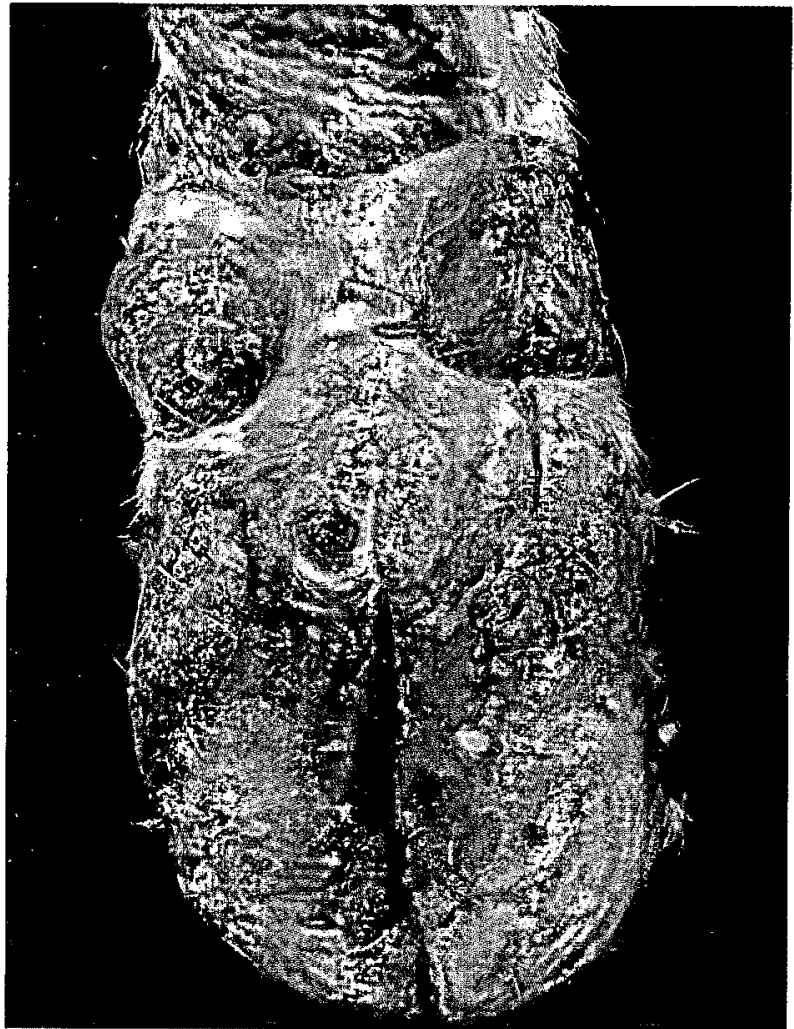

Figure 3A. Digital dermatitis lesions, before application of oxytetracycline and hoof boot.

Şekil 3A. Oksitetrasiklin ve ayak çizmesi uygulamasından önceki digital dermatitis lezyonu.

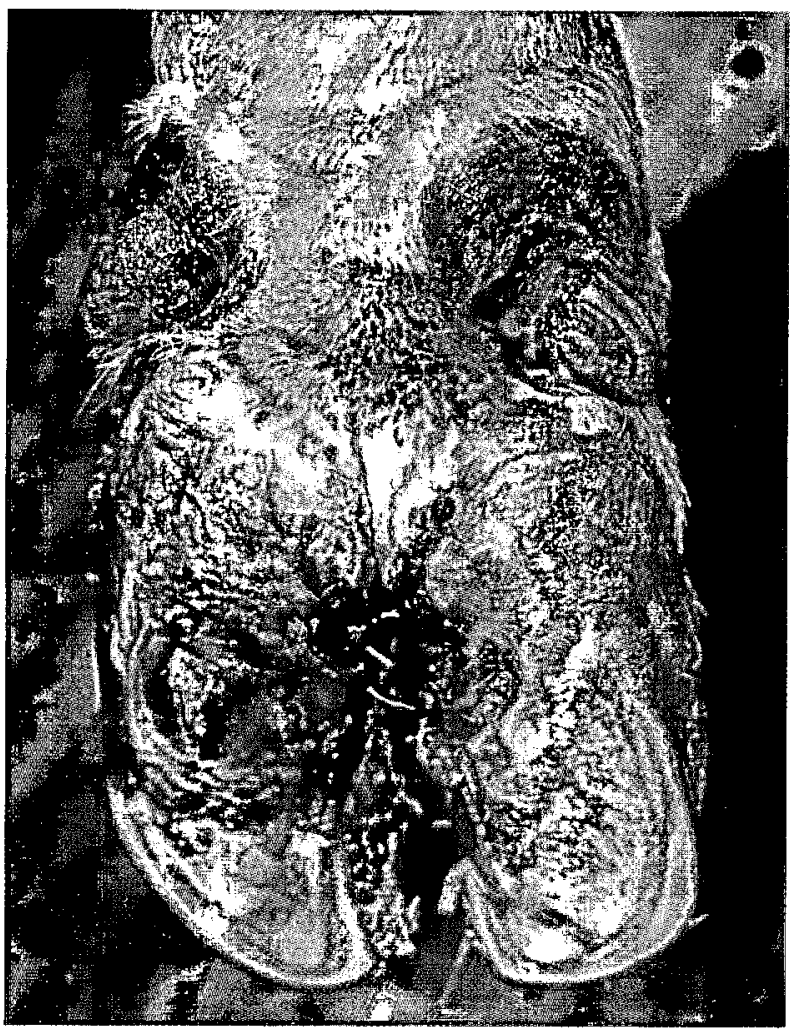

Figure 3B. Digital dermatitis lesions, 14 days after application of oxytetracycline and hoof boot.

Şckil 3B. Oksitetrasiklin ve ayak çizmesi uygulamasını takiben 14 gün sonraki digital dermatitis lezyonu.

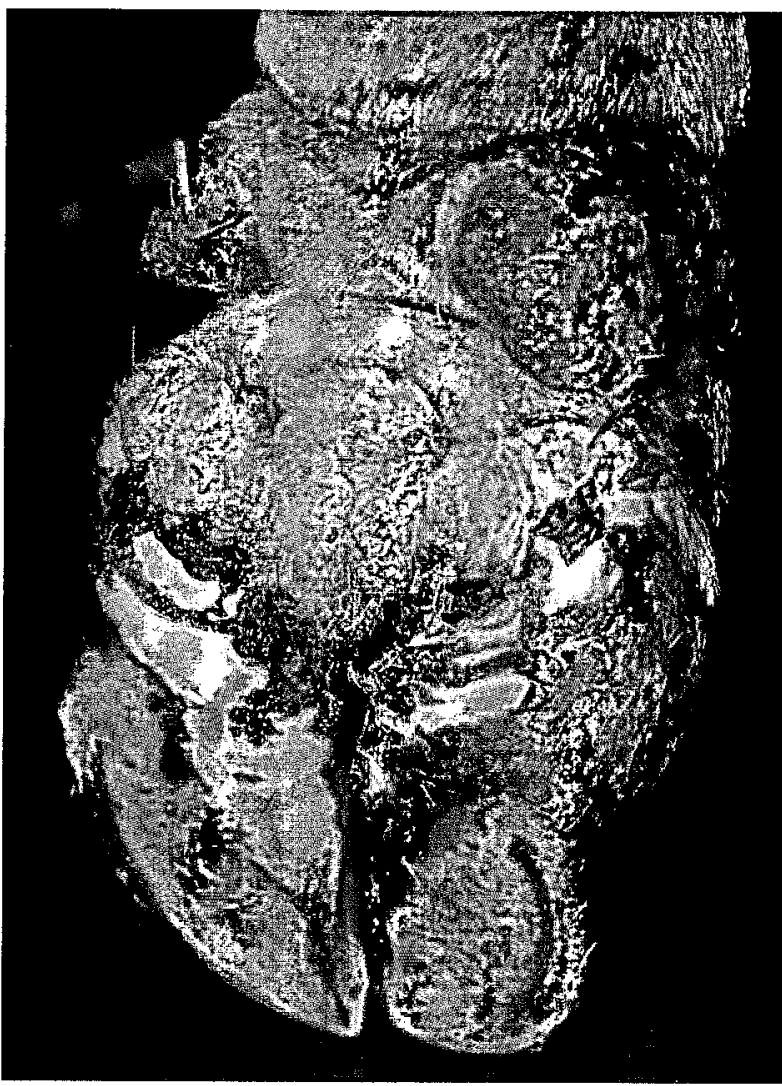

Figure 4. Digital dermatitis lesion treated with only saline solution and left open (after 30 days). Note papillomatous form of digital dermatitis developed.

Şekil 4. Sadece serum fizyolojik uygulamasını takiben açık bırakılan digital dermatitis lezyonu (30. gün). Digital dermatitisin papillomatoz formunun gelişimi.

Differences between GI-a and GI-b were statistically significant $(\mathrm{p}<0.01)$. A similar pattern was also seen between group II-a and II-b $(p<0.01)$. GI-c and GI$\mathrm{d}$ were also statistically different as seen in GII-c and GII-d (p<0.01)

There was a negative association between the severity of lesions and improvement of locomotion. When the lesion regressed, the locomotion of the cow improved.

\section{Discussion and Conclusion}

The granulation tissue was similar to strawberrylike papilliform defect in the skin as previously described by Mortellaro et al (20).

Economic losses due to lameness encouraged researchers to focus on preventing and treating foot infections. Large amount of grants have been directed toward the understanding and spread of the infectious digital lameness among dairy cattle. However, there have still been some problems associated with eradication of foot infections on herd basis (4). Use of antimicobials is also other great concern regarding human consumption. Therefore parenteral administration of antimicrobials in animals near market should be avoided and local applications may be the choice for these individuals $(6,12)$. 
Oxytetracylines have been widely used for the treatment of infectious foot disorders $(1,7,24,25)$.

The study indicated that use of hoof boot improved the healing process of DD and IDD and appeared to be highly effective. Hoof boot is easy to apply and reusable after disinfection. It is reasonably orthopedics in nature and can be applied to any feet of cows. We believe that hoof boot not only protect the foot but also protect the composition and structure of antimicrobials drugs against environmental offensive materials such as debris, urine and mud etc. In addition, it also protects the germs to spread from cow to cow. After application of hoof boot no need for further physical support was required in this study.

Stockmanship is also an important factor; comparatively low standards have been related to a high prevalence of lameness (28). Poor knowledge and awareness of farmers on the subject of cattle lameness, and inadequate training in foot care, has been associated with a high prevalence of digital disorders (17). Recently, it was shown that two applications of oxytetracycline after trimming were significantly more effective and cured $87 \%$ of cases of DD investigated (14). However, the current study provided resolution for the treatment of DD after single application of oxytetracycline. In an other study (19) either nonantimicrobial cream or lincomycin paste was used to treat DD but efficacy of 2 treatments was not significantly different. This may be explained that local lincomycin application has a limited antimicrobial effect against DD-associated organisms.

It was concluded that the treatment of DD and IDD with local oxytetracycline application alone might not be sufficient. But, use of hoof boot adjacent to the treatment could hasten the recovery period. The author hopes that the data generated here provide valuable information on tackling DD and IDD problem.

\section{References}

1. Adams OR (1960): Foot rot in cattle. J Am Vet Med Assoc, 136, 589-599.

2. Amstutz HE (1985): Prevention and control of lameness in dairy cattle. Vet Clin North Am: Food Anim Pract, 1, 25-37.

3. Andersson L, Lundstrom K (1981): The influence of breed, age, body weight and season on digital diseases and hoof size in dairy cattle. J Vet Med A, 28, 141151.

4. Berry S, Read DH, Wlaker RL (1999): Recurrence of papillomatous digital dermatitis (footwarts) in dairy cows after treatment with lincomycin $\mathrm{HCl}$ or oxytetracycline $\mathrm{HCl}$. J Dairy Sci, 82, 34.

5. Blood DC, Studdert VP (1993): Lameness. 520. In: Baillere's Comprehensive Veterinary Dictionary. $3^{\text {rd }}$ impression. Bailliere Tindall, London.

6. Britt JS, Carson MC, von Bredow JD, Condon RJ (1999): Antibiotic residues in milk samples obtained from cows after treatment for papillomatous digital dermatitis. J Am Vet Med Assoc, 215, 833-836.

7. Blowey RW (1994): Studies on the pathogenesis and control of digital dermatitis. $8^{\text {th }}$ International Symposium on Disorders of the Ruminant Digit and Conference on
Bovine Lameness, University of Saskatchewan, Banff, 2630 June, Canada, 142-154.

8. Brizzi A (1990): Bovine digital dermatitis treatment trials. Obiett e Doc Vet, 11, 51-54.

9. Collick DW, Ward WR Dobson H (1989): Association between types of lameness and fertility. Vet $\operatorname{Rec}, 125,103-$ 106.

10. Dewes HF (1978): Some aspects of lameness in dairy cattle. New Z Vet J, 26, 147-149.

11. Esslemont $\mathbf{R}$ (1990): The costs of lameness in dairy herds. Proceedings of the $6^{\text {th }}$ International Symposium on Diseases of the Ruminant Digit. British Cattie Veterinary Association, University of Liverpool, 16-20 July. UK, 237-251.

12. Green LE, Hedges VJ, Schukken YH, Blowey RW, Packington AJ (2002): The impact of clinical lameness on the milk yield of dairy cows. J Dairy Sci, 85, 22502256.

13. Greenough PR, MacCallum FJ Weaver AD (1981): Diseases of digital skin and subcutis. 151-169. In: Lameness in Cattle. $2^{\text {nd }}$ edition, Wright Scientechnica, Bristol.

14. Manske T, Hultgren J, Bergsten C (2002): Topical treatment of digital dermatitis associated with severe heelhorn erosion in a Swedish dairy herd. Prev Vet Med, 53, 215-231.

15. Merritt JB, Manson FJ Russell WB Downham DY (1992): The effect of lameness on milk production in friesian-holstein cows. Proceedings of $104^{\text {th }}$ Meeting of the British Society of Animal Production. Scarborough, 46 April, UK, 479-480

16. Mgasa MN, Mgongo FOK, Munjuni PF (1990): The economic importance of lameness in imported dairy cattle in Tanzania. Proceedings of the $6^{\text {th }}$ International Symposium on Diseases of the Ruminant Digit. British Cattle Veterinary Association, University of Liverpool, 16-20 July, UK, 258.

17. Mill J.M, Ward WR (1994): Lameness in dairy cows and farmers' knowledge, training and awareness. Vet Rec, 134, 162-164.

18. Minitab Inc. (2000): Minitab 13.I statistical program. 3081 Enterprise Drive, State College, PA $16801-3008$, USA.

19. Moore DA, Berry SL, Truscot ML, Koziy V (2001) Efficacy of a nonantimicrobial cream administered topically for treatment of digital dermatitis in dairy cattle. $\mathrm{J}$ Am Vet Med Assoc, 219, 1435-1438.

20. Mortellaro CM, Romussi S Scavia G (1994): Preliminary report on the onset and evolution of digital skin diseases in a group of 32 heifers. $8^{\text {th }}$ International Symposium on Disorders of the Ruminant Digit and Conference on Bovine Lameness. University of Saskatchewan, Banff, 26-30 June, Canada, 177-179.

21. Potter MJ, Broom DM (1990): Behaviour and welfare aspects of cattle lameness in relation to building design. Proceedings of the $6^{\text {th }}$ International Symposium on Diseases of the Ruminant Digit. British Cattle Veterinary Association, University of Liverpool, 16-20 July, UK, 8084.

22. Russell AM, Rowlands GJ Shaw SR Weaver AD (1982): Survey of lameness in British dairy cattle. Vet Rec, 111, 155-160.

23. Tranter WP, Morris RS Dohoo IR Williams NB (1993): A case-control study of lameness in dairy cows. Prev Vet Med, 15, 191-203. 
24. Shearer JK, Elliott JB (1994): Preliminary results from a spray application of oxytetracycline to treat, control and prevent digital dermatitis in dairy herds. $8^{\text {th }}$ International Symposium on Disorders of the Ruminant Digit and Conference on Bovine Lameness. University of Saskatchewan, Banff, 26-30 June, Canada, 182.

25. Sheldon IM (1994): Digital and interdigital dematitis in dairy cattle. Vet Rec, 134, 559-560.

26. Systat Inc. (1990-1992): 1800 Sharman Avenue, Evanstone, IL. USA. 60201.

27. Ward WR (1994a): The minimal solution footbath-an aid to treatment of digital dermatitis. $8^{\text {th }}$ International Symposium on Disorders of the Ruminant Digit and Conference on Bovine Lameness. University of Saskatchewan, Banff, 26-30 July, Canada, 184-185.

28. Ward WR (1994b): The role of stockmanship in foot lameness in UK dairy cattle. $8^{\text {th }}$ International Symposium on Disorders of the Ruminant Digit and Conference on Bovine Lameness. University of Saskatchewan, Banff, 2630 July, Canada, 301-302.
29. Weaver AD (1994): International terminology of digital diseases. $8^{\text {th }}$ International Symposium on Disorders of the Ruminant Digit and Conference on Bovine Lameness. University of Saskatchewan, Banff, Canada, 25-28.

30. Young GB, Lee GJ Waddington D Sales DI Bradley JS Spooner RL (1983): Culling and wastage in dairy cows in East Anglia. Vet Rec, 113, 107-111.

Geliș Tarihi.06.05.2003 Kabul Tarihi 15.09.2003

\author{
Yazışma adresi: \\ Yrd. Doç. Dr. Ibrahim Demirkan \\ Afyon Kocatepe Üniversitesi \\ Veteriner Fakulltesi \\ Cerrahi Anabilim Dalt \\ 03200-Afyon \\ e-mail:demirkan007@hotmail.com
}

